\title{
The Co-Construction of Energy Provision and Everyday Practice: Integrating Heat Pumps in Social Housing in England
}

\author{
Ellis P Judson, Sandra Bell, Harriet Bulkeley, Gareth Powells \& Stephen \\ Lyon
}

Challenges of energy security, low carbon transitions, and electricity network constraints have led to a shift to new, efficient technologies for household energy services. Studies of such technological innovations usually focus on consumer information and changes in behaviour to realise their full potential. We suggest that regarding such technologies in existing energy provision systems opens up questions concerning how and why such interventions are delivered. We argue that we must understand the ways by which energy systems are co-constituted through the habits and expectations of households, their technologies and appliances, alongside arrangements associated with large-scale socio-technical infrastructures. Drawing on research with air-source-to-water heat pumps (ASWHP), installed as part of a large trans-disciplinary, utility-led research and demonstration project in the north of England, we investigate how energy services provision and everyday practice shapes new technologies uptake, and how such technologies mediate and reconfigure relations between users, providers and infrastructure networks. While the installation of ASWHP has led to role differentiation through which energy services are provided, the space for new forms of co-provision to emerge is limited by existing commitments to delivering energy services. Simultaneously, new forms of interdependency emerge between users, providers and intermediaries through sites of installation, instruction, repair and feedback. We find that although new technologies do lead to the rearrangement of practices, this is often disrupted by obduracy in the conventions and habits around domestic heating and hot water practices that have been established in relation to existing systems of provision. Rather being simply a matter of increasing levels of knowledge in order to ensure that such technologies are adopted efficiently and effectively, our paper demonstrates how systemic arrangements of energy provision and everyday practice are co-implicated in socio-technical innovation by changing the nature of energy supply and use.

Keywords: air source heat pump, diffusion, innovation, social housing, social practices, socio-technical systems, smart grid 


\section{Introduction}

The United Kingdom, alongside other European countries has set ambitious longterm $\mathrm{CO}_{2}$ reduction and renewable energy targets, which have become key drivers in shaping energy policy. The UK government aims to cut greenhouse gas emissions by $80 \%$ from 1990 levels by 2050, with implications for energy supply and demand. Increasing renewable sources of energy is a key element of the UK strategy. Future projections of carbon emission savings rely on widespread uptake of a range of low carbon energy sources (DECC, 2013) including small scale, low and zero carbon micro-generation heat technologies (HM Government, 2009; EST, 2007). Heat pumps are a key technology for delivering lowcarbon heating (DECC, 2011; Spiers et al., 2010). European Union policy encourages the wider uptake of heat pumps by including them in a list of renewable technologies designed to meet national obligations to increase the percentage of heat generated from renewable sources (EU, 2009). For the UK this entails a shift away from dependence on ubiquitous gas powered domestic central heating to technologies powered by new forms of low carbon electricity. However, there are uncertainties over how this new electricity system can be realised, and how consumers might relate to unfamiliar heating technologies. Current understanding of how novel low carbon thermal technologies become integrated into homes is limited (Wrapson \& DevineWright, 2014).

This study aims to increase understanding of how low carbon heating technologies are accommodated within the household and how heating practices might change to realise policy objectives. Further understanding this process requires examining how provision and use of energy services through domestic practices are co- constituted and assessing their potential for change. Elements of provision and of practices vary across countries and sometimes regions within countries. Here we draw on initial findings from the Customer Led Network Revolution (CLNR) project, an industry-led and regulatorfunded trans-disciplinary project located in the north east of England involving qualitative research conducted among participants recently fitted with an airsource-to-water heat pump (ASWHP).

This paper argues for a perspective that unites all elements of energy production, distribution and consumption under the single concept of $a$ system of provision. We explore an example provided by empirical research on heat pump installations in social housing, an emerging market and focus of activity. We illustrate the dynamics entailed in a whole systems approach by exploring the ways that ASWHP installations in existing housing schemes open up the order of energy provision and consumption, creating and closing down spaces for alternative modes of consumption based on the co-provision of services on the one hand and reconstituting interdependencies between users, providers and systems on the other. These dynamics of co-provision and interdependence respond to alterations at different points in the system. We focus on changes that occur through technological innovation in the form of ASWHPs, and the ensuing adaptation of practices in which they constitute a material element (Shove et al., 2012: 32). We also consider the wider perspective and how its formation is reconfigured or reinforced.

An overview of the main domestic heating technologies in the UK is followed by a summary of the factors underlying adoption and diffusion of heat pumps, and review of previous studies on retrofitting heat pumps in existing housing. The second section of the paper outlines how 
implementation of low carbon technologies in domestic spaces is positioned to meet UK objectives to achieve a decarbonised energy system and how such innovations are conceived in technical and social terms. In the third section, we introduce the project and our methods. The fourth section of the paper considers how ASWHPs might reconfigure and reinforce systems of energy provision. In section five we examine the extent to which ASWHPs are 'domesticated' within practices, and conclude by reflecting on the implications of our findings.

\section{The Context: Heating Systems in the UK}

Around 20.5 million dwellings in the UK ( $90 \%$ of the housing stock) have central heating as their main heating system, 1.6 million dwellings (7\%) have storage heaters, and 0.7 million dwellings (3\%) have room heaters. In 2011, the proportion of households using gas for their central heating was $91 \%$, with less than $1 \%$ solid fuel, just $2 \%$ electricity, and oil $4 \%$ (DECC, 2013a). Wet-based gas central heating dominates space and water heating, in the main areas in which gas is available (Hoggett et al., 2011). Direct electric heating or night storage technologies are also reasonably prevalent, with households in remote locations less likely to have access to gas than those in urban areas (DCLG, 2013). Some households make use of coal, wood and other solid fuels to provide heating services. Modes of operation of ASWHPs differ from these conventional heating systems (Table 1). Thus, for many UK households, ASWHPs represent a changed experience of heating provision that demand new skills (Gram-Hanssen et al., 2012; Heiskanen et al., 2014).

In the UK, heat pump technologies are closely tied to the synchronous development of smart grids and de-carbonisation. In this context, government policy identifies ground and air source heat pumps as a means to reduce carbon intensive technologies for space heating (e.g. BERR, 2008; DECC, 2011; HM Government, 2009) though their adoption lags behind mainland Europe and North America, with the uptake of ASHP particularly sluggish (Singh et al., 2010). Financial support for the installation of heat pumps is available from the government to homeowners and landlords through the Renewable Heat Incentive, launched April 2014 (DECC, 2013b), replacing the Renewable Heat Premium Payment (RHPP), and promoted by quasi government intuitions such as the Energy Saving Trust.

\section{Uptake of Heat Pumps}

Different authors highlight different 'factors' to explain the uptake of heat pumps in a particular context (e.g. Fawcett, 2011; IEA, 2010; NERA \& AEA, 2009; Singh et al., 2010). These include: climate, government policy on energy and environmental issues, energy prices, availability of competing energy sources, electricity supply and generation characteristics, housing characteristics, history, geography and geology. The market penetration of heat pumps in the UK remains small. Heat pumps providing both space and water heating are most popular (Roy et al., 2008), with the majority located in new residential buildings and in dwellings without mains gas (EST, 2010). This ostensibly makes optimum gains in domestic energy efficiency by replacing electrical heating systems.

Given the large stock of older, thermally inefficient dwellings, the UK retrofit market presents significant potential and challenges. Limitations to the widespread adoption of ASWHPs identified in previous studies are: initial capital costs (compared to common alternatives), underperformance, technical difficulties, preferences for other familiar and reliable technologies, inertia, a small-scale and fragmented heat pump 


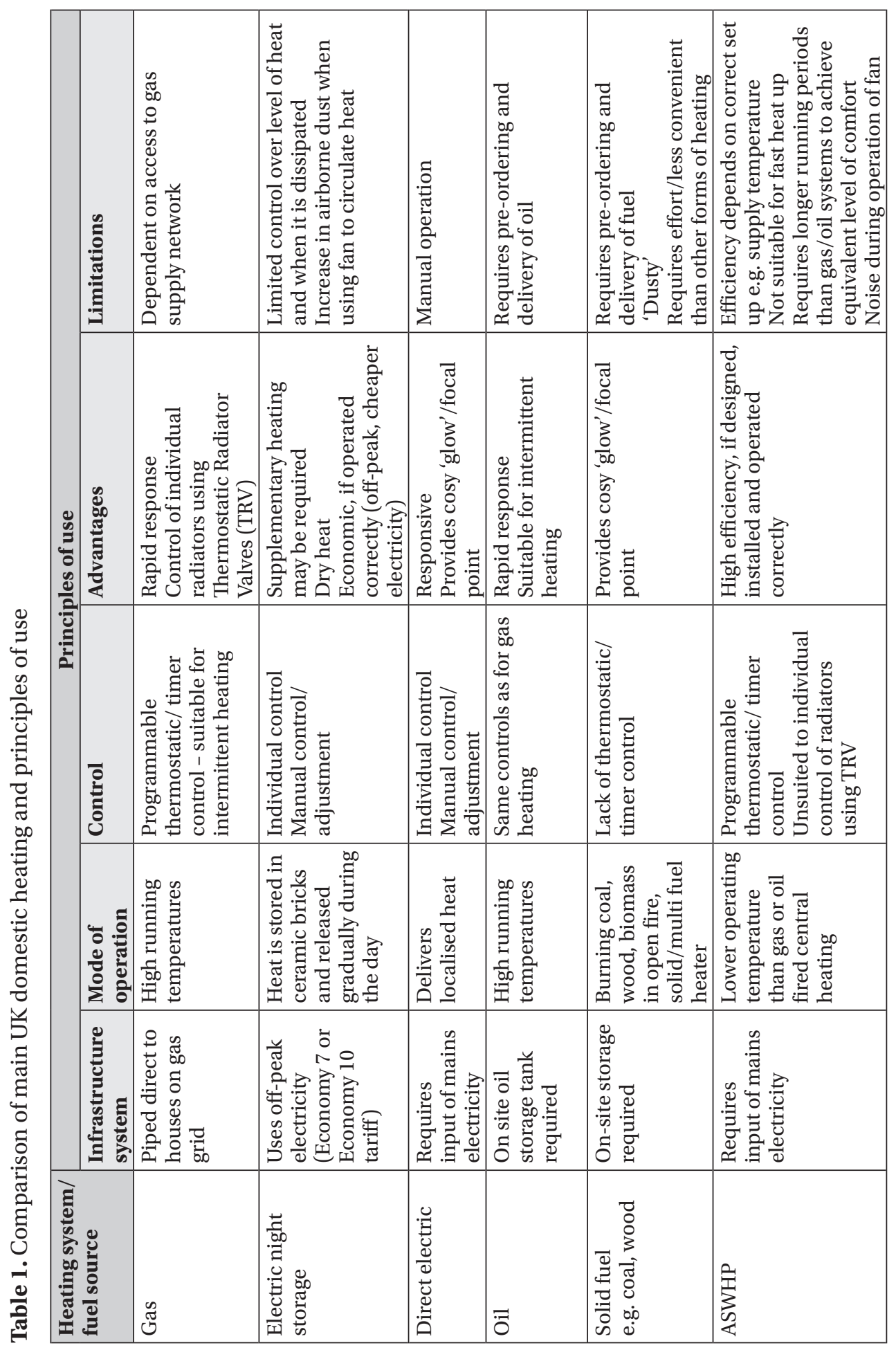


installer industry, skill deficits, and other institutional barriers (Bergman, 2013; Caird et al., 2012; Element Energy \& NERA, 2011; EST, 2010; Fawcett, 2011; Hoggett et al., 2011; Pither \& Doyle, 2005). Installing heat pumps in existing dwellings requires the retrofit of energy efficiency measures, and the transition to a low temperature heat distribution system, which could be both costly and disruptive to install in an existing property-particularly where underfloor heating is required (Fawcett, 2011). ASWHPs are smaller and cheaper, with lower installation costs than GSHPs, and better suited for the retrofit market. The focus of this paper is on retrofitting ASWHPs in social housing as an emerging market segment. Social housing accounts for 5 million dwellings, or 18 per cent of the UK housing stock (ONS, 2014). Social housing providers are installing heat pumps to reduce heating bills (Bergman, 2013). However, several studies and reports on householder experiences (e.g. EST, 2010; Hoggett et al., 2011; Stockton, 2011) identify problems around installation and use of ASWHPs, particularly amongst social housing tenants.

Table 2. Heat pump retrofit studies

\begin{tabular}{|c|c|c|c|c|}
\hline & Year & Units/participants & $\begin{array}{l}\text { Heat distribution } \\
\text { system/DHW }\end{array}$ & Method \\
\hline \multicolumn{5}{|l|}{ UK studies } \\
\hline $\begin{array}{l}\text { Pither \& Doyle } \\
\text { UK }\end{array}$ & 2005 & $\begin{array}{l}\text { GSHP (56) } \\
\text { ASWHP (1) } \\
57 \text { units in } 7 \text { case study } \\
\text { projects, of which } 35 \text { are } \\
\text { retrofit } \\
\text { Social housing tenants (54) } \\
\text { Owner-occupiers (2) }\end{array}$ & $\begin{array}{l}\text { Various configurations, } \\
\text { mainly DHW and } \\
\text { radiators for space } \\
\text { heating }\end{array}$ & $\begin{array}{l}\text { Survey (18 resp.) of which } \\
16 \text { social housing tenants, } \\
\text { and } 2 \text { owner occupiers }\end{array}$ \\
\hline $\begin{array}{l}\text { Energy Saving } \\
\text { Trust \& Scottish } \\
\text { Government } \\
\text { UK }\end{array}$ & 2008 & $\begin{array}{l}\text { GSHP }(22) \\
\text { ASWHP }(34) \\
\text { Social housing tenants (56) } \\
\text { Owner-occupiers (31) }\end{array}$ & $\begin{array}{l}\text { Various configurations, } \\
\text { mainly DHW and } \\
\text { radiators }\end{array}$ & $\begin{array}{l}\text { Daily diaries, survey (75 } \\
\text { resp.) and telephone } \\
\text { interviews }\end{array}$ \\
\hline $\begin{array}{l}\text { Energy Saving Trust } \\
\text { (Phase 1) } \\
\text { UK }\end{array}$ & $\begin{array}{l}2008- \\
2010\end{array}$ & $\begin{array}{l}\text { GSHP (54) } \\
\text { ASWHP (29) } \\
\text { Mixed: Owner-occupiers } \\
\text { and social housing tenants } \\
(83)\end{array}$ & $\begin{array}{l}\text { Heating (21\% UFH; } 14 \% \\
\text { Mixed; } 64 \% \text { radiators) } \\
\text { and DHW }(73 \%)[1]\end{array}$ & Detailed monitoring (83) \\
\hline $\begin{array}{l}\text { Boait et al. } \\
\text { UK }\end{array}$ & 2011 & $\begin{array}{l}\text { Social housing } \\
\text { GSHP (10) }\end{array}$ & DHW and radiators & Detailed monitoring (10) \\
\hline $\begin{array}{l}\text { Stafford \& Lilley } \\
\text { UK }\end{array}$ & 2012 & $\begin{array}{l}\text { Social housing } \\
\text { GSHP (10) }\end{array}$ & DHW and radiators & $\begin{array}{l}\text { Detailed monitoring (10) } \\
\text { and social/behavioural } \\
\text { investigations }\end{array}$ \\
\hline $\begin{array}{l}\text { Caird et al. } \\
\text { UK }\end{array}$ & 2012 & $\begin{array}{l}\text { Owner-occupiers (48) } \\
\text { Social housing tenants (30) }\end{array}$ & $\begin{array}{l}\text { Various configurations, } \\
\text { mainly DHW and } \\
\text { radiators (36); DHW } \\
\text { and underfloor heating } \\
(17)\end{array}$ & $\begin{array}{l}\text { In depth user survey (78 } \\
\text { resp.); focus group with } \\
\text { social housing tenants }\end{array}$ \\
\hline $\begin{array}{l}\text { Owen et al. } \\
\text { UK }\end{array}$ & 2012 & $\begin{array}{l}\text { ASWHP (12) } \\
\text { Owner-occupiers (12) }\end{array}$ & $\begin{array}{l}\text { Space heating (not } \\
\text { specified) and DHW }\end{array}$ & $\begin{array}{l}\text { Interviews with: owner- } \\
\text { occupiers (6); programme } \\
\text { managers (2); surveyors/ } \\
\text { installers (4) }\end{array}$ \\
\hline $\begin{array}{l}\text { Energy Saving Trust } \\
\text { (Phase 2) } \\
\text { UK }[1]\end{array}$ & $\begin{array}{l}2010- \\
2012\end{array}$ & $\begin{array}{l}\text { Mixed: Owner-occupiers } \\
\text { and social housing tenants } \\
(44)\end{array}$ & $\begin{array}{l}\text { Various configurations, } \\
\text { mainly space heating } \\
\text { and DHW (33) }\end{array}$ & $\begin{array}{l}\text { Detailed monitoring } \\
\text { Face to face and } \\
\text { telephone interviews (35) }\end{array}$ \\
\hline
\end{tabular}


Table 2 cont.

\begin{tabular}{|c|c|c|c|c|}
\hline & Year & Units/participants & $\begin{array}{l}\text { Heat distribution } \\
\text { system/DHW }\end{array}$ & Method \\
\hline \multicolumn{5}{|c|}{ Other European studies } \\
\hline FAWA, Switzerland & $\begin{array}{l}1996- \\
2003\end{array}$ & 221 (existing 40\%) [1] & $\begin{array}{l}\text { Space heating (54\% } \\
\text { UFH) and 50\% DHW [1] }\end{array}$ & $\begin{array}{l}\text { Detailed monitoring; } \\
\text { survey }[2,3,4] \\
\text { New and existing } \\
\text { buildings }\end{array}$ \\
\hline $\begin{array}{l}\text { Stenlund \& Axell, } \\
\text { SPTRI, Sweden }\end{array}$ & 2007 & GSHP (5) & Space heating and DHW & $\begin{array}{l}\text { Detailed monitoring ( } 5 \\
\text { dwellings); survey ( } 251 \\
\text { resp.); interviews (25) }\end{array}$ \\
\hline Lahr, Germany & 2009 & $\begin{array}{l}\text { ASHP (12) } \\
\text { GSHP (13) }\end{array}$ & Unknown & Detailed monitoring [2] \\
\hline $\begin{array}{l}\text { Elvari } \\
\text { Finland }\end{array}$ & 2010 & ASHP (78) & Unknown & Unknown [6] \\
\hline $\begin{array}{l}\text { Russ et al. } \\
\text { Fraunhofer ISE } \\
\text { Germany }\end{array}$ & 2010 & $\begin{array}{l}\text { ASHP (36) } \\
\text { GSHP (36) }\end{array}$ & $\begin{array}{l}\text { Heating (3\% UFH; } 26 \% \\
\text { Mixed; } 71 \% \text { radiators) } \\
\text { and DHW }(100 \%)\end{array}$ & $\begin{array}{l}\text { Detailed monitoring }[2 \text {, } \\
5,7]\end{array}$ \\
\hline $\begin{array}{l}\text { Pedersen et } \\
\text { al. Danish } \\
\text { Technological } \\
\text { Institute Denmark }\end{array}$ & 2012 & $\begin{array}{l}\text { ASHP (12) } \\
\text { GSHP (138) }\end{array}$ & $\begin{array}{l}\text { Heating ( } 16 \% \text { UFH; } 70 \% \\
\text { Mixed; } 14 \% \text { radiators) } \\
\text { and DHW }(100 \%)\end{array}$ & Detailed monitoring [2] \\
\hline $\begin{array}{l}\text { Gram-Hanssen, } \\
\text { Christenson \& } \\
\text { Petersen } \\
\text { Denmark }\end{array}$ & 2012 & $\begin{array}{l}\text { ASHP (481) } \\
\text { Owner-occupiers }\end{array}$ & $\begin{array}{l}\text { Space heating and } \\
\text { cooling }\end{array}$ & $\begin{array}{l}\text { Survey (481 resp.); } \\
\text { electricity consumption } \\
\text { data ( } 180 \text { households); } \\
\text { face-to-face interviews } \\
\text { (12) }\end{array}$ \\
\hline $\begin{array}{l}\text { SEPEMO } \\
\text { Austria, France, } \\
\text { Germany, Greece, } \\
\text { Netherlands, } \\
\text { Sweden }\end{array}$ & $\begin{array}{l}2009- \\
2012\end{array}$ & ASHP, ASWHP, GSHP (52) & Space heating and DHW & $\begin{array}{l}\text { Detailed monitoring } \\
\text { (44) of new and existing } \\
\text { dwellings [8] }\end{array}$ \\
\hline $\begin{array}{l}\text { Winther \& Wilhite } \\
\text { Norway }\end{array}$ & 2014 & $\begin{array}{l}\text { ASHP (22) } \\
\text { ASWHP (2) } \\
\text { GSHP (4) } \\
\text { Owner-occupiers (27) } \\
\text { Tenants (1) }\end{array}$ & Unknown & $\begin{array}{l}\text { Face-to-face interviews } \\
\text { (28) }\end{array}$ \\
\hline
\end{tabular}

[1] See also Bradford J \& Byrne T (2013) The UK heat pump field trial: findings from phase 2. ECEEE 2013 Summer Study. The European Council for an Energy Efficient Economy (ECEEE).

[2] This study is not available in English. Details obtained from Gleeson C P \& Lowe R (2013) Meta-analysis of European heat pump field trial efficiencies. Energy and Buildings 66: 637-647.

[3] EHPA (European Heat Pump Association) (2010) European Heat Pump News 12(2) August 2010.

[4] IEA (2004) Heat Pump Centre Newsletter 22(2).

[5] Staffell I, Brett D, Brandon N \& Hawkes A (2012) A review of domestic heat pumps. Energy \& Environmental Science 5(11): 9291-9306.

[6] Motiva (2010) Jälkiasennetun ilmalämpöpumpun vaikutus energiankäyttöön. Available at: http://www.motiva. fi/files/3960/Jalkiasennetun_ilmalampopumpun_vaikutus_energiankayttoon.pdf (accessed: 26.11.2015).

[7] See also Miara M, Günther D \& Langner R (2013) Efficiency of heat pump systems under real operating conditions. In: IEA Heat Pump Center Newsletter 31 (2013) No. 2: 22-26. Available at: http://publica.fraunhofer. de/documents/N-256404.html (accessed 30.11.2014).

[8] Nordman R (2012) SEasonal PErformance factor and MOnitoring for heat pump systems in the building sector SEPEMO-Build. Final report. Available online: http://ec.europa.eu/energy/intelligent/projects/sites/iee-projects/ files/projects/documents/sepemo-build_final_report_sepemo_build_en.pdf (accessed 26.11.2015). 
There is a risk of heat pumps not delivering expected energy or carbon savings (Bergman, 2013; Caird et al., 2012; Fawcett, 2011; Wrapson \& DevineWright, 2014). A further concern is that electrification of heating (and use of heat pumps for summer cooling) will contribute to increases in residential electricity demands, putting additional strains on distribution networks (Element Energy \& NERA, 2011; Hoggett et al., 2011; Skiers et al., 2010).

\section{Heat Pumps in Existing Housing: Performance}

This section reviews available published studies on retrofitting heat pumps in existing domestic dwellings (summarised in Table 2). Many studies focus on monitoring efficiency and technical factors affecting performance (e.g. Boait et al., 2011; EST, 2010). There is little available information on householders' experiences and practices of using heat pumps, despite users' affecting heat pump efficiency (DECC, 2013c; Miara et al., 2013; Stafford \& Lilley, 2012). The main UK evidence comes from the Energy Savings Trust (EST, 2010, 2013) and Caird et al. (2012), the largest UK heat pump study and comprised of both owner-occupiers and social housing tenants. The study by Owen et al. (2012) includes interviews with 12 owner-occupiers, of which five participants were retired, and three householders had significant health problems. The remaining UK studies in Table 2 are predominantly concerned with social housing. It was not possible to determine tenure in all other European studies. Previous studies (Caird et al., 2012; Pither \& Doyle, 2005) indicate that social housing residents were more dissatisfied with their heat pump systems than private householders, particularly with regard to running costs, technical support and comparison with their previous heating system. In the survey by Pither \& Doyle
(2005), 33\% of respondents gave the highest score for effectiveness of heating. However, $17 \%$ rated heating as average and 2 participants gave a very low score. Provision of hot water rated more highly than heating. Forty per cent of occupants thought more instructions were needed, and $34 \%$ thought that heat pumps were too expensive to run. These findings are also reflected in a study published by DECC (2013b). Although the survey by Caird et al. (2012) found that most users were satisfied with the reliability, heating, hot water, and comfort provided by their system, significant differences were observed in efficiency between owneroccupied dwellings and social housing. Owner-occupiers' greater satisfaction with space heating (79\% satisfied) and comfort (91\% satisfied) compared to social housing residents (67\% and $71 \%$ satisfied), is attributed to interaction between differences in the systems, dwellings and users at the private and social housing sites. Higher system efficiencies were associated with greater user understanding of their heat pump system, and how users operate the system.

Concerns remain about whether ASWHPs potential can be realised, especially in the extent to which inefficient installation and use of heat pumps can reduce performance (EST, 2010; Fawcett, 2011). Empirical investigation shows that performance of domestic heat pumps varies considerably across installations, with ASHPs rarely achieving maximal design efficiency. The UK's largest independent field trial on heat pump technology, which monitored 83 heat pumps in residential properties for 12 months, found the coefficient of performance $(\mathrm{COP})^{1}$ ranged between 1.2 and 3.3. The average system efficiency of GSHP was 2.39, and the average for ASWHP was 1.82, lower than in other European studies (for example, Christensen et al., 2011), with most of the installed systems 
not reaching the estimated benchmark for 'renewable energy' (Staffell et al., 2015: 116). This study demonstrates the complex range of interacting variables affecting performance, including UK weather conditions, installation and commissioning practices, and customer behaviour. Many householders had difficulty understanding their heat pump operating instructions (EST, 2010). Previous studies indicate that potential energy efficiency gains may be compromised by householders' use of heat pumps: a study of Danish dwellings, (Gram-Hanssen et al., 2012) concludes that expected reductions in electricity consumption are only partially achieved in real life settings. Similar findings were reported in a recent study of 28 Norwegian households (Wither \& Wilhite, 2014), confirming the findings of the UK EST trials-that energy efficiency gains may be compromised not only by the design and installation of heat pumps, but by their use.

\section{Linking Provision and Practice}

A systems of provision perspective recognises the relationship between providers of energy services, the consumers of those services, and infrastructures (Chappells et al., 2000); and comprises the assemblage of institutions, agencies, material elements, mechanisms, and practices that might enable the transformation of energy systems to reduce $\mathrm{CO}_{2}$ emissions.

We suggest that examination of the current discrepancy between uptake and government targets for the expansion of domestic heat pumps in the UK moves away from conceptualising the fate of innovations as lying in the hands of an individual consumer and engages with the ways production and consumption of energy co-evolve and are mediated through the work of everyday practice. Relations between the provision of energy services and the practices through which they are enrolled are critical for understanding how a new technology such as heat pumps is embraced, sidelined or contested within the home.

Whilst the dynamics of these relations exist at multiple levels and involve multiple actors, the research reported here envisages the socio-technology of heat pumps largely through the eyes of new adopters and defines the energy services they receive as combined with everyday household practices, leading to what van Vliet (2012: 263) describes as 'a practice-inclusive perspective' of energy systems, including infrastructure networks. The relationship between wider systems and the household is conceptualised by Schatzchi (2015: 15) as 'bundles of practices and material arrangements', the latter being 'collections of people, artefacts, organisms and things that are linked by such matter as contiguity, causality and physical connections'. Electricity networks are organised around connections that physically link consumers to providers (Southerton et al., 2004). Viewed in this way, the ASWHP becomes the intermediate physical connection linking the electricity network and household practices of thermal comfort, cleanliness and airing.

The systems of provision perspective challenges the conventional conceptualisation of infrastructure networks as mostly represented in linear and straightforward terms, where resources are captured, generated, and supplied to meet consumer demands. Spaargaren (2011:816) notes that although householders are 'being served' by utility companies, householders in turn can be said to 'serve' energy systems by reproducing their specific socio-technical regimes (Geels, 2004) for the provision to householders. Rather than being linked through a functional, unidirectional relationship, the providers and consumers 
of services are dynamically connected in ways that co-produce the system (Shove \& Walker, 2010; Southerton et al., 2004). From this perspective, the habits and expectations of households, and the technologies and objects they use interact with and mutually shape each other, along with arrangements associated with large-scale socio-technical systems (Sofoulis \& Williams, 2008). In this manner, the production and consumption of services are linked through distinct 'systems of provision', which encompass different resources, providers, consumers and mediating technologies that interact and are structured through the 'connective tissue' of 'infrastructures and regulatory arrangements' (van Vliet et al., 2005: 116). The reordering of provision and rearrangement of social practices such as is required for the adoption of heat pumps for domestic heat and hot water in the UK involves renewal, reconfiguration and contestation at a number of different levels.

The concept of domestication is regarded as useful in offering insight into how technologies are integrated into households, where integration is described as involving processes of negotiation with the technology, and as encompassing stages of adaptation and use (Aune, 2001; Juntunen, 2012). In understanding possible changes that take place in relation to the technology, Aune (2001: 8) suggests that the wider system may be as important as the use of the device. To understand the nature and extent of the domestication of ASWHPs, we consider the interrelation between current systems of provision, interventions, and integration with household practices.

\section{Re-Ordering of Provision}

In the linear model of large technical systems energy companies often enjoy monopolistic and hence hegemonic positions in the market place, leading them to adopt what Strengers (2013:
123) describes as a utilitarian position, promoting a reality where household energy requirements are solely determined and controlled by individual home appliance owners. Whereas in the heralded future of disaggregated co-provision and smart energy appliances digital savvy, homeowning householders are invited to hand over control of electricity use to distributors and suppliers under the guise of greater efficiency and time-saving convenience. Neither of these images yet reflects the average UK heat pump user, who is currently most likely a tenant in social housing (Fawcett, 2011).

Nevertheless, control and operation of a heat pump positions the user as participating in the provision of their own energy services and redefines their consumer role from 'captive consumer' associated with a previous universal mode of service in multiple ways (van Vliet et al., 2005; Walker \& Cass, 2007), creating new possibilities for users not only to unwittingly collaborate in the reproduction of energy systems but to act as 'co-providers' of energy services. Consumers turned 'co-providers' are able to generate some of their own technological and institutional services (van Vliet et al., 2005: 49). In the UK, as elsewhere, the deployment and uptake of low carbon energy technologies within households are serving to create the basis for the emergence of alternative modes of consumption, generating requirements for renegotiation of new forms of interdependency between service providers, users and systems (van Vliet et al., 2005). Such renegotiations may involve users seeking to break away from their roles as 'captive' consumers, but may also involve establishing new forms of dependency on a widening range of service providers. For example, research in Harlow Park, a sustainable housing development in Liverpool, found that even simple tasks required negotiation with housing 
providers, with the consequence that consumers are 'locked' into relationships of dependency (van Vliet et al., 2005: 85).

Furthermore, adjustments to new systems of provision introduced by social intermediaries such as landlords may be welcomed or resisted as an imposition. In the latter case disengagement means features of the new system of provision are rejected. In terms of domestication, people need time to understand and engage with new technologies and their ability to do so is often influenced by their experience with older, familiar appliances and systems of provision (Haddon, 2006). Faced with innovation in provision the same user might compare the new to the familiar favourably in some respects and unfavourably in others, depending on adjustments to elements and linkages within social practices like achieving thermal comfort or personal care regimes.

Heat pumps are acknowledged as not the easiest or most likely technology for invention, even though modifying heat pumps after installation has been observed elsewhere (Hyysalo et al., 2013).

\section{Re-Arrangement of Practices}

Rather than being a matter of individual behaviour, energy provision and use is shaped by the practices that constitute everyday life (Shove et al., 2012). Understanding energy using a practice theoretical approach means attending to the ways that consumption is configured in mundane activities and how everyday life is conducted, from cooking, washing, providing care, keeping warm or cool and so on. Practices are achieved through

routinized (types) of behaviour which consists of several elements, interconnected to one another: forms of bodily activities, forms of mental activities, "things" and their use, a background knowledge in the form of understanding, know-how, states of emotion and motivational knowledge (Reckwitz, 2002: 249).

Conceived as the interconnection of interdependent elements in possession of their own logics and dynamics, practices persist and evolve as new elements are inserted or taken up. Significantly, the emphasis within practice theories is on the importance of artefacts and technologies as essential to practices (Shove et al., 2012). However, the focus in most materiallyoriented practice accounts remains on the role of discrete objects, artefacts and technologies rather than wider infrastructure arrangements (Strengers \& Maller, 2012).

Understanding how the 'roll out' of domestic ASWHPs is undertaken, its effects and the focus on technologies within practice theories has two important implications. First, technologies such as ASWHP do not figure in isolation but are constitutive of systems of provision as well as practice (Spaargaren, 2011). Second, there is a need to develop understanding of what constitutes the material components of practice, away from a focus on individual objects to material arrangements in order to engage with the ways in which practices intersect with systems of provision.

Institutional actors support new systems of provision through various means (Schatzki, 2015), which in the case of ASWHPs in the UK, includes governmentsponsored agencies such as The Energy Saving Trust, and a range of initiatives to encourage consumers to invest in microgeneration, including The Low Carbon Buildings Programme (LCBP); the Carbon Emissions Reduction Target (CERT); the Green Deal; and, most recently, the Renewable Heat Incentive (RHI). To overcome reported design, installation 
and commissioning problems, an installers' certification scheme (MCS) was introduced for microgeneration in 2008, and specification of minimum technical competences, along with incorporation of minimum standards in the building regulations for low-carbon energy sources (DCLG, 2014).

Institutional actors inject certain expectations into the altered systems of provision that require the reconfiguration of domestic practices to follow trajectories towards particular outcomes. Inclusion of heat pumps in the UK government's Renewable Heat Incentive scheme is part of wider ambitions to reconfigure sociotechnical practices and reduce GHG emissions. But this requires the adaptation of domestic practices towards 'appropriate' usage of heat pumps in ways that prevent consumers frequently using booster options or turning to supplementary heating. These elements of household practice can bring unintended consequences by increasing energy consumption and compromising the intentions of policy intervention. Heat pumps operate at optimum efficiency when their low level heat production is distributed continuously via under floor heating or radiators with surfaces greater than those commonly used with gas boilers. Switching to uninterrupted use contrasts with the 'blasts' of heat experienced when gas boilers fire up or electric storage heaters peak and fade and can be disconcerting for users and requires the establishment of new routines. Failure to adjust other elements of practice around the use of heat or hot water can result in inefficiencies in the new system of provision and loss of intended gains.

New technologies, user roles, forms of know-how, design, operation and so on serve to re-work existing forms of practice in ways that cannot always be anticipated to serve particular ends. In what follows, we explore the ways that ASWHPs generate openings for new forms of energy provision and consumption, whilst at the same time creating and closing down spaces for alternative modes of consumption based on the co-provision of services on the one hand and reconstituting interdependencies between users, providers and systems on the other. We consider how these dynamics of co-provision and interdependence are mediated through everyday practices of comfort, cleanliness and airing, demonstrating that it is in the interrelation between current systems of provision, interventions, and practice that enables understanding of the nature and extent of the domestication of ASWHPs. Before turning to these issues, we first introduce the research project from which this analysis is drawn and the methodologies that were employed.

\section{The Customer Led Network Revolution (CLNR) Project and Methodology}

The core objectives of the project include understanding current and likely future energy demand and examining the potential for fostering customer flexibility within the domestic and SME sectors. In order to address these objectives, and in line with the socio-technical approach adopted, the CLNR project is designed around a number of 'test cells' each of which entails a different combination of households, SMEs, low carbon technologies, tariffs, smart meters and/or monitoring equipment. Overall, the project involves the participation of over 12,600 energy customers, with the majority forming a control group that includes 8,900 domestic customers, all of which have smart meters from which half-hourly energy consumption data is recorded. The remaining customers are participating in various experimental trials and technologyspecific 'control' studies ${ }^{2}$. Understanding 
why some household practices may adapt to the electrical landscapes created and why others remain unchanged and how these varying responses intersect will contribute to knowledge of the co-construction of electricity systems and practices.

\section{Methodology}

This paper draws on qualitative interviews and home energy tours conducted with 18 households recruited from the 378 domestic customers involved in the ASWHP trial who agreed to participate in a home interview with researchers. Each of the households with an ASWHP has advanced monitoring that relays electricity consumption to the supplier every ten minutes but no other form of intervention. Participants with ASWHP were contacted directly by one of the research team, using information provided by the energy retailer, which had previously identified households that were willing to participate. The semi-structured interviews focused on building rapport with the participant while discussing their energy use in general terms. These conversations included information about occupancy, major electrical loads, heating regimes, washing and cooking practices, thoughts and feelings about electricity use, seasonality and other temporal factors as well as experiences of and responses to new technologies. Interviews were focused on two clusters within the regional network: social housing tenants in South Tyneside and County Durham. Social housing landlords had installed loft and wall insulation, where feasible, and retrofitted an ASWHP at no cost to the tenants. Interview participants had lived with the ASWHP for between 6-12 months, including the winter months. Interviews were conducted between January and March 2013.

In South Tyneside ASWHPs replaced electric night storage heaters, gas-ducted air and solid fuel/ back boilers, funded through the Renewable Heat Premium Payment, Carbon Emissions Reduction Target (CERT), Community Energy Saving Programme (CESP), and British Gas. Installation of the air-to-water system, which distributes heat via a wet central heating system, took place following engagement with tenants of interwar housing in a suburban location, which included individual surveys, an invitation to attend a meeting at a local community centre, and visits to a fully operational Show Home so tenants could see an unfamiliar technology installed and experience its effects in an almost identical domestic setting. The refusal rate amongst tenants was reportedly low, mainly limited to cases of ill-health. (South Tyneside Homes, 2012)

In rural County Durham, 24 ASWHP were fitted in a social housing retirement development of terraced one bedroom, single story dwellings. The properties were built between 1900-1910, and previously supplied by a communal gas boiler that provided piped hot water and heating to all the homes in the complex. As a result of these contexts, it should be noted that the participants from whom evidence is drawn, are representative of older and more vulnerable households. The majority are retired or semi-retired, living in small ( 1 or 2 bedroom) properties.

Interviews typically lasted 60 to 90 minutes, including home tour, and were digitally recorded. Household details, audio recordings, photographs, and drawings were collected with participants' consent, and analysed together with field notes and interviewers' reflections. A qualitative data analysis (QDA) software package, NVivo 9, was used to organise and thematically code data.

Below, we explore some of our initial findings and analysis related to the ways in which ASWHPs have come to intervene in the energy provision system, and 
implications for household routines and practices.

\section{ASWHPs in Social Housing and Provision of Energy Services}

\section{The Legacy of Existing Systems}

Adoption and use may be influenced by initial contacts between users and the technology, as suggested by Owen et al., (2012), however, discussions with our participants revealed the importance of the legacy of existing heating systems in shaping the ways people related to the introduction of the ASWHP, an aspect acknowledged as significant by Owen et al. (2012) and Juntunen (2014). Participants with a communal system of heating and hot water reported that it was 'tip top' (Male tenant, DC031) and they 'never had no problems' (Male tenant, DC035). In contrast, participants who had lived with electric storage heating systems, regarded ASWHPs as a considerable improvement to dependence on various expensive forms of electrically produced heat:

'You had no heat. They [storage heaters] were supposed to stay warm all day but they were cold by 11 o'clock so you were freezing. I had to use the electric fire all the time... but now I hardly ever use it... Well, I was putting £35 to 40 a week on with the storage radiators but now I'm putting $£ 20$ on now. I couldn't have afforded the other. It was terrible'. (Female tenant, ST004)

'You had no control over them [...] when I come in [from work] in the evening, the place was cold. They only have bricks with a heating element, so once they switch off at 7 o'clock [in the morning] they start cooling down, so by the time I'm getting here in at 7-8 o'clock [in the evening] or whatever, the place was cold and I can't do anything. I can't turn the heating on cause they won't switch on again until midnight, and I've got no control.' (Male tenant, ST011)

Among those who had managed to control their night-storage heating system, the ASWHP was initially resisted, but where participants had felt unable to achieve the kinds of thermal comfort they required the possibility of improvement was greatly welcomed; not least because it seemed to offer a new means to control their energy services either by reducing dependence on and cost of portable electrical heaters or because of the perceived challenge of controlling the pre-existing system. Optimising the performance of the ASWHP requires users to adopt different patterns of energy use based on its continual, lowlevel provision (Cantor, 2011). Users' expectations and practices are critical in shaping how the system is operated. For some, existing daily routines over-rode the system imperatives, and users played an active role in reshaping the technology to their needs:

\footnotetext{
'When I'm working shifts what I normally do when I go out first thing in the morning I'll switch it off completely. [...] so then put it on auto for 5 o'clock, or if it gets too cold, like the last few weeks, I'll just come in and put it on.' (Male tenant, ST011)
}

For others, the ASWHP necessitated a new mode of operation and patterns of use surrounding domestic space heating and hot water. Householders with electric night storage were familiar with the Economy 7 tariff and this enabled understanding that the ASWHP heated water during the early hours of the morning. However, some were advised they could not continue the 
cheaper nighttime tariff for the AHSP, which led to confusion.

'We try not to have the water and the heating on together because it pulls too much, so the water comes on on a morning then it goes off for a little while. It's not that it's expensive, it's just my husband being careful. If you've got heating and hot water on the water doesn't heat up as much [...] so we just don't put the heating on.' (Couple, ST010)

For many, the demands of active participation in the provision of energy services seemed too great. Some had tried and failed to ensure that the ASWHP

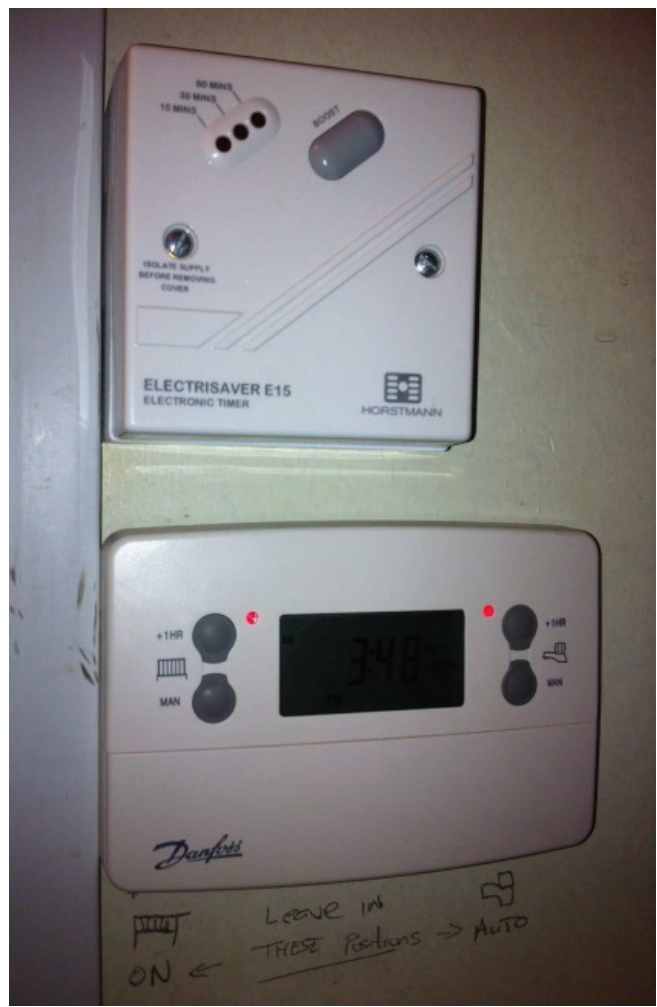

Figure 1(a). Hot water boost (top) and main control with handwritten instruction to leave in set positions (below) provided the energy services they required. Several had concerns about whether running the system all day-technically the most efficient usage-would incur additional costs (see also Owen et al., 2012). Others sought to distance themselves from the technology, fearing their actions may lead to the breakdown of the system and loss of heating and hot water.

'That's the control which I do NOT touch. I operate it from the thermostat.' (Female tenant, ST005)

'I don't let anybody touch anything. I don't want to know. As long as it's working, I don't want to know.' (Female tenant, ST009)

In these cases, co-provision of energy services is not celebrated, but resisted, ignored or feared. This may reflect the social and demographic make-up of the sample of participants, and their position as tenants in social housing over which they may traditionally have held little sway. At the same time, they also reflect the process of installation and instruction that participants experienced, as suggested by

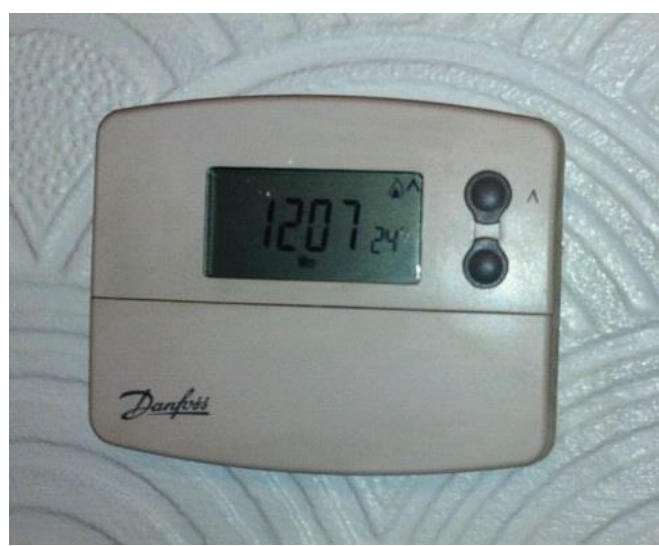

Figure 1(b). Thermostat control 
Owen et al. (2012). Many participants found the system operating instructions difficult to grasp and the controls made little sense. Recounting the advice received from the social housing provider on re-setting the system, householders remained confused:

'If it goes off and needs reset... Switch
it off from the inside, then switch it off
from the outside. Give it a couple of
minutes then switch it back on from the
outside first, then come in and switch
it on from the inside. And that should
re-set it. [...] The people I am asking
information off I don't think they are
fully aware with it being a new system
and that. [...] I'm not sure whether they
know that much about it.' (Male tenant,
ST011)

Despite that, at the time of interview, most householders reached a point where they were able to operate the system at a basic level using the up and down arrows on the thermostat (Figure 1[b]), but they stuck to the programme set initially on installation:

'They just put it in and I've left it as it was [...] I wouldn't know what to do. That's the only trouble. They didn't really tell you much about anything.' (Female tenant, ST004)

A few more technically literate had changed the programme settings to suit their own preferences or understandings, however, even the more competent had some difficulty with the technical information supplied, as illustrated by the comments from a recently retired electrical engineer:

'I wasn't happy with the times they had set. So I tried to set the timer myself. So eventually I got there. Reading the book over and over and over again.' (Male tenant, ST008)
Others found they had poor grasp of how the system operated and what to do, particularly outside of normal operating conditions:

\begin{abstract}
'The red light starts flashing and I just do not know why. And I think, 'Oh God there's something wrong.' Nobody told me that the light would go flashing red, you know. When you don't know, naturally I am the age that I worry.'

(Female tenant, ST009)
\end{abstract}

These responses echo the findings of the wider UK EST trial by judging the operations and controls of their ASWHP systems as 'baffling'; a fact that is notable in comparison to a Danish study where references to the intricacies of using the technology do not feature, despite respondents being 'in general older and less affluent than the rest of the population' (Gram-Hanssen et al., 2012: 265). This suggests that how installation and instruction are undertaken is critical in shaping the initial reception of ASWHPs and the extent to which users become willing participants (Owen et al., 2012). It also echoes the finding that the scope for autonomy, which in turn appears to shape the extent to which users are able to reconsider their roles as passive consumers and engage in forms of co-provision, is shaped by the degree providers are willing to delegate responsibilities or instead import their own notions of 'sustainable living' through interventions (van Vliet et al., 2005). Through these means, the deployment of ASWHPs appears caught in an uneasy tension between new patterns of energy use and modes of operation required from users on the one hand and the continued focus on consumers as passive recipients of energy services on the other. 


\section{Creation of New Interdependencies}

The negotiation over what it entails to be an operator and user of ASWHPs, between household members, users and providers, and various agents also requires a reworking of interdependencies across the system of energy service provision. Such forms of negotiation and interdependence were visible when the ASWHP failed or required some form of technical intervention. Users, puzzled by the control and operation of the system, turn to a range of trusted providers for support but often found they too had limited understanding of the system and effective solutions:

'Got the plumber in and the plumber looked and says, "I don't know anything about this system" and he's gone. Why didn't they train these people? [...] I'm still worried about that [leak from the tank].' (Male tenant, ST010)

'He [housing maintenance officer] was here about an hour and a half. They hadn't been trained. He didn't know what to do. He felt awful. I got all the brochures out, he looked through them and studied them, he went out the back. He didn't know what [...] so he got onto his boss. [...] Then [the installer] come out on the Monday [...] so I'd had no hot water and heating since Friday. The [IT engineer] had turned the electric off and hadn't put it back on... I was having to boil a kettle to have a wash [...] It was like the 1920s.' (Female tenant, ST006)

While households could marshal different coping mechanisms, several reported that the breakdown of the system, both technically and in terms of the usual means through which energy services were provided, repaired and restored, led to significant disruption:

\begin{abstract}
'A lot of people still do not understand the heat system... I was without heat for a week. I don't know. It just went off. It just didn't work. And I was freezing, absolutely freezing.' (Female tenant, ST005)
\end{abstract}

'I had three air source heat pumps put in. The first two were no good. I was without heating for a month... They were broken when they were first put it. [...] It was February/March, so it was pretty cold.' (Female tenant, ST004)

Users of ASWHPs became dependent on a new constellation of providers. Social landlords and utility companies were reliant on manufactures and specialist repair services that were misaligned in the management and repair of this particular technological innovation. At the same time, providers and installers regarded users as critical to effective operation of the system to deliver energy services. Users were also dependent on others to determine the success or otherwise of the technology. Having lived with the ASWHP for several months, many householders remained uncertain about the performance of the ASWHP:

'[We] still really don't know if we're saving anything. We've got this wireless system in that sends information to [electricity retailer] but we haven't had any reports back or anything like that.' (Male tenant, ST010)

The interview data indicates that householders do not 'actively' manage electricity consumption or read their electricity meter regularly, but continue to rely on their electricity provider to provide this information through periodic, usually quarterly, billing. For most householders interviewed, consumption is evaluated 
based on cost, not kWh used. Energy pricing is not straightforward, with some energy suppliers exacting a standing charge (a fixed daily charge), along with different unit rates for peak and off-peak electricity depending on the tariff, so difficult to calculate. Even where householders monitor electricity consumption, most do not understand how the system works, and are unlikely to know how to optimise their ASWHP for most efficient operation (Boait et al., 2011; Caird et al., 2012).

Far from being a straightforward installation of a technological device, this analysis demonstrates how the intervention of ASWHPs in existing systems of provision entails the reworking of the roles of providers, users and intermediaries from relatively stable positions to a more differentiated system where roles are multiple and dynamic, subject to contestation and resistance. The processes of installation, instruction, repair and feedback provide some of the sites in which this negotiation occurs, whereby new forms of interdependency are realised and negotiated, providing one explanation as to why other studies (e.g. Owen et al., 2012) have found that the initial encounters with ASWHPs are critical to their 'social lives' in households (Bauman, 2013). The ways that systems of provision are (re)aligned, enable role differentiation, and create space for coprovision appears critical for understanding how and why ASWHPs are and are not able to realise their potential. These processes are conditioned through the ways heating and hot water are used within household practices, which in turn serve to provide the means through which ASWHPs become domesticated, taken up or left out of the provision and use of energy.

\section{Domesticating AWSHP: The Re- Arrangement of Existing Routines and Practices}

Pantzar (1997: 65) argues technological systems exist only 'in and through' their reproduction in micro-social interactions, inferring that the household is a fruitful location for understanding processes of technological domestication. Reflecting on the concept and 'process' of domestication outlined earlier, and drawing on interviews with users, we consider the extent to which ASWHPs are integrated within practices of comfort, cleanliness, drying laundry and so on.

Here we consider how householders might adapt familiar patterns of interaction surrounding previous systems of provision to assemble new routines associated with ASWHP. As indicated in Table 1, ASWHP creates a strikingly different resource for practices relating to thermal comfort, when compared with other forms of heating. UK householders in our study who converted from gas-fired central heating tended to conceptualise the newly installed ASWHP as a boiler, anticipating a similarly rapid response only to find discrepancies between cooler running radiator temperatures produced by an ASWHP and higher running temperatures of boiler fired radiators (cf. Owens et al., 2012). Comparison with the old system of provision can lead to resistance to the new, which may be perceived as failing to meet established standards of performance.

'The radiators never get hot... When I first set the timer. I'm getting up half past six and they're freezing cold. It takes an hour for the pump to run to get them warmed up.' (Male tenant, ST008)

In the UK these notions of thermal comfort-rapid response and high running temperatures-are linked to expectations 
of uninterruptable supplies of hot water in order to meet what have become incontrovertible conventions of cleanliness for bodies, clothes and homes (Chappells \& Shove, 2004). In recent decades, the development and dissemination of gas or oil fired hot water central heating systems facilitated on-tap hot water for bathing, laundering or washing dishes. The affordances offered by this co-evolution of hot water and heating services fostered assumptions that cleanliness regimes are ideally carried out in thermally 'comfortable' homes: creating a perfect circle of energy consumption associated with relatively cheap and plentiful North Sea gas (Brinkley \& Mcllveen, 2010). ASWHPs challenge these widespread assumptions and related practices by prompting novel meanings and actions that may be adopted with more or less certainty. Some changes to practices were observed: for example in our study where dwellings previously had electric night storage heating, the main change noted after installation of ASWHP occurred around using supplementary heating. Some people gladly abandoned supplementary heat sources. However, householders retained an electric heater with a flame effect for the cosy 'glow', and because it acted as a 'focal point'-valued features that the ASWHP could not provide. It also served as back-up in case of technical failure. Others adopted caution towards sole dependence on ASWHP and even considered reverting to supplementary heating.

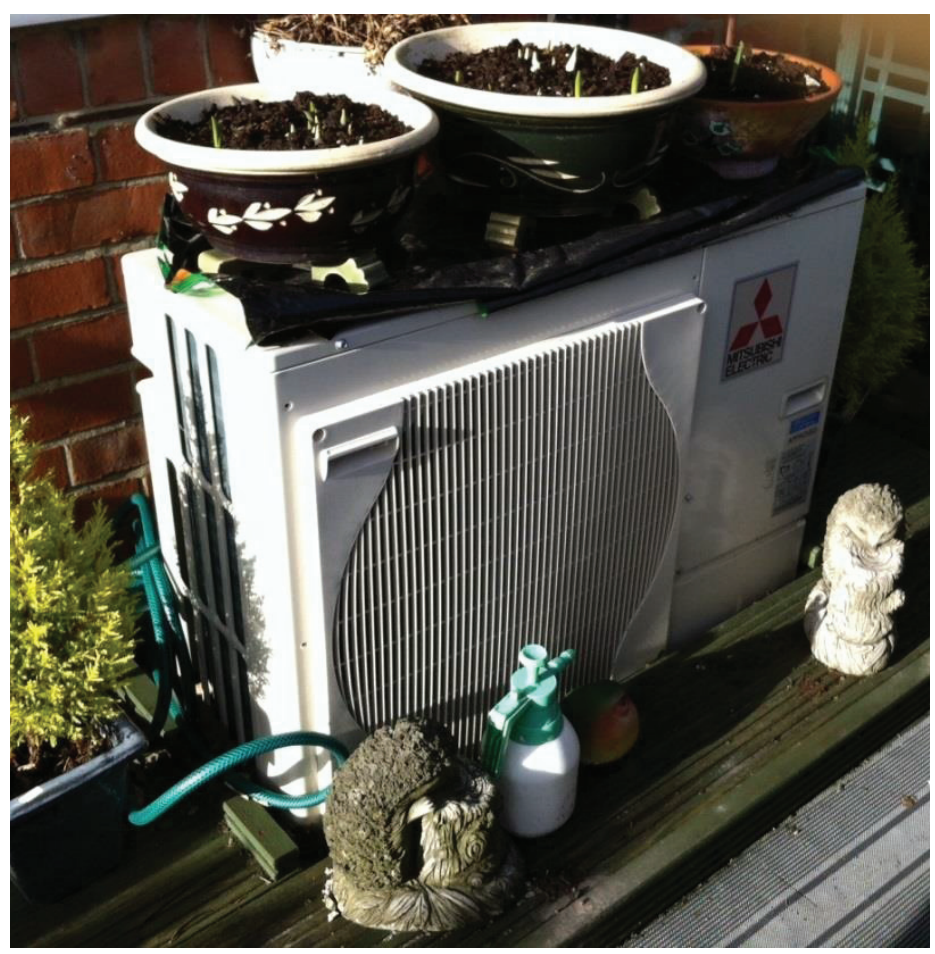

Figure 2. Air source to water heat pump external unit, South Tyneside, showing new elements being fitted into the existing physical external space. This example indicates how integration between the old and the new extends beyond the immediate energy related practices such as heating, washing and ventilation, to other activities such as gardening. 
Strathern (1994: vii) defines domestication as 'the manner in which people convert things to ends of their own' Viewed like this the newly installed ASWHP can be understood as a focus for negotiating new and unfamiliar practices within the everyday dynamics of household relations. These processes of technological transition, however innovative, 'work on what is already there, what already gives shape to people's lives' (Strathern 1994: vi). Hence take-up of ASWHPs in the UK is bound to understandings and know-how associated with currently dominant space heating regimes, so people who move from gas boiler to ASWHP have to acclimatise to lacking instant availability of heating and to lower ambient temperatures.

'The radiators, they don't actually get as hot as your conventional heaters' (Male tenant, ST007).

Householders shifting from storage heaters (with or without supplementary heating) and electric hot water systems make adjustments that sometimes result in lowered awareness of their energy use and lead to high rates of electricity consumption.

'The booster is brilliant. [...] if we've let the water get too cold. It takes less than an hour' Couple (ST010).

There is a danger for ASWHPs to actually increase energy consumption (e.g. Winther \& Wilhite, 2014) leading some researchers to conclude that depending on context, installation procedures and demographic factors, as well as variations in dwellings and the purposes they serve, a heat pump can be viewed as 'a wolf in sheep's clothing' (Christensen et al., 2011). However one potential counteraction to increased electricity consumption following installation of heat pumps in dwellings previously fitted with electric night storage heating are changes to the use of supplementary heating. Some householders discontinued supplementary heating altogether-

'I don't use that [electric fire] now... I used to when I had the storage heaters though' (Male tenant, ST011).

In this case a once desirable resource is dispensed with and another practice that of relying on the ASWHP for thermal comfort is configured. However, this energy saving effect is not universal as others are more reluctant to depend solely on ASWHP

'I was thinking about getting one of those gas ones, just in case [...] I used to have a one but got rid of it. I wish I'd never have done now' (Male tenant, DC032). In this case an old resource and associated practice is resurrected out of apprehension about the new technology.

\section{Learning New Practices}

In some cases, householders found their potential to engage in the rearrangement of practices disrupted by existing desires, understandings and routines that were able to change only incrementally, if at all. For others, the perceived technological intricacies of the ASWHP and uncertainties about who would manage the technology and ensure that their needs were met led to feelings of resistance and alienation. In other cases, however, we found that the arrival of new technologies was welcomed and existing practices were either able to encompass the new technology and the forms of heat and hot water it provided, or rapidly reconfigured in order to do so.

Constructing a satisfactory fit between established practices and emerging ones 
comes more easily to some householders and in relation to certain practices. For example, the fact that the ASWHP generates a different kind of heat to her old system led one woman to declare: 'I'm glad I've got it in now because it dries the washing beautifully' (Female tenant, ST005). Hot water provision is considered the least problematic change. Householders judge the service provided by the ASWHP to be equivalent or better than previous systems. Overall, hot water practices remained largely unchanged mainly because the new system meets users' expectations and exerts no adaptive pressure.

There is little evidence of changes in established ventilation practices following the installation of the ASWHP. Householders with a declared long standing liking for 'fresh air' continued to leave windows open through the day, and sometimes overnight, while keeping the heating on. One householder abandoned open windows as a solution to over-heating because the lower-running temperature of the ASWHP resolved the problem.

Many tenants felt disempowered by their landlords' decision to introduce the new heating and water heating technology and did not know how to adjust household practices accordingly. Some were afraid of the ASWHP and tried to distance themselves from it while living apprehensively with the unavoidable consequences of its presence. Interviews demonstrate feelings of alienation to be more or less extreme according to age, gender, experience and single occupancy. The most alienated and troubled users in our sample are elderly women, living alone who regarded themselves as technologically ignorant, although problems are not restricted to these users.

\section{Enabling Changes to Energy Provision through Intermediaries}

As well as landlords, installers and suppliers are implicated in fostering forms of inertia that countervail the technological innovation. They fail to enact their necessary new role as effective innovation intermediaries (Bessant \& Rush, 1995; Howells, 2006) between users and the new technology, specifically user side intermediaries (Stewart \& Hyysalo, 2008). Users receive insufficient explanation and interpretation of the ASWHP and lack postinstallation advice and oversight. Better follow up services tailored to the specific user groups could enable installers to also act as intermediaries between housing tenants and landlord. The latter are not as familiar with or well informed about ASWHP performance as installers. Whilst installers are in the best position to assist tenants to make the transition to a new technology with a user interface that appears complex to people with low levels of technical knowhow, the interview data suggests they may lack the capacity-necessitating changes to the way heat pump retrofit projects are formulated and implemented.

There is scope for considering new business models for the provision of low carbon energy systems, for example one where 'servicing' a heating system was not focused on the technology (e.g. the boiler) but instead 'practice' (e.g. of comfort), giving hands on advice and passing on know-how, in a way that was regularly repeated. It might also suggest new roles for practice intermediaries in the domestic provision and use of energy services, such as in this case in social housing; this represents a new or extended intermediary role for landlords, focusing on enactment. A subset of user side innovation intermediaries, practice intermediaries seek to engage with users to assemble elements and linkages to configure usage of the ASWHP 
and associated practices, and facilitate recruitment to new forms of practice in relation to the use of energy through, for example, peer-to-peer learning between different housing developments which have 'lived through' ASWHPs, to hands on demonstrations of how such technologies work within the context of ordinary homes and everyday routines. The importance of learning through peer-to-peer interaction is recognised by Heiskanen et al. (2014), as is online advice and peer support (Hyysalo et al., 2013b), in appropriating heat pumps. Similar arguments have been made under the concept of 'local experts' (Stewart, 2007) and user side innovation intermediaries regarding ICT use. Rather than regarding users as simply passive adopters of new technologies, such approaches would recognise the vital work that users perform in maintaining and transforming energy systems, and a basis through which to engage households in new ways of thinking about and 'doing' energy use.

The domestication of an 'all electric' system of provision involves configuring infrastructure, bureaucracies, manufacturers, installers and service providers together with householders' routines, competencies and knowledge, acquired and transacted within their social groups and entrenched in everyday life (Elzen et al., 2004). Additionally, we must integrate an understanding of things as active 'participants' in social worlds in order to understand the impact of low carbon technologies on energy systems.

\section{Conclusion}

The preceding analysis raises several key points for understanding how novel low carbon thermal technologies become integrated into households everyday life, and implications for changing practices, and systems of provision. From installation and study of household practices for a short period after, this study makes visible various practices of integrating technology as part of everyday life, providing insight into the details of installation and use. It reveals the constellation of different actors and diverse interests required to make ASWHPs effective. This perspective is critical for the UK where housing and energy are separately organised and structured, without integrated policy contexts (e.g. of municipal ownership of both housing and energy systems when fuel is paid for through rent) that exist in other locations where heat pumps are widely adopted.

Rather than being a straightforward matter of the insertion of technologies within domestic spaces, we have argued that understanding the roll out of new low carbon technologies needs to be couched in an understanding of how such systems are co-constituted in the interrelation between the provision of energy services and user practices. A newly installed domestic heat pump stands at the interface between new and old practices and wider systems of provision, which include energy infrastructure and housing providers. While the sample included in this study may have experienced particular challenges, given their socio-demographic background and their position as tenants in social housing with implications for engagement with the technology, these findings accord with the results of other studies which have found that ASWHPs do not always perform as expected. ASWHPs are taken up within existing social relations and everyday practices, such that rather than being adopted in the manner by which designers intend, they are assimilated within the particular socio-technical contexts. Far from being a universal solution, ASWHP introduce considerable disjunction in systems of provision in the UK. Our results demonstrate that it is insufficient to 'roll 
out' technologies without considering the distributed relationships involved, and the need for local configuration of multiple logics.

The challenge involved in reconfiguring systems of provision and re-ordering practices is further illustrated by the complexity of relations involved between tenants, social housing landlords, suppliers, installers and electricity providers. Emerging from the context of these changing systems of provision and new forms of sustainable practice is a need for user-side intermediaries-to bring together the social and the technical. The severe paucity of information and coaching in the use of ASWHP indicates a role for different forms of intermediaries: whether to provide user-side support to recruit occupants to new practices, installer training on engaging with users, and chains of support from manufacturers.

Although the number of households may be a limitation of the study, results suggest that the social response to ASWHPs is far from homogenous, varies considerably even within similar socio-demographic and housing tenure contexts, and are shaped by the legacies of the systems of provision that are removed to make way for ASWHPs and the forms of everyday practices within which these technologies and the services they provide are enrolled.

The findings of this study are particularly important in a context where significant emphasis is being placed on the potential of new domestic technologies to advance a low carbon transition. Effective strategies to encourage integration of heat pumps requires policy-makers be informed by improved understanding of how they become embedded within existing thermal systems and practices. Current models of deployment tend to assume that, provided with basic information, users will come to learn how to use new technologies efficiently. This study suggests that this is not the case. Instead the desires, understandings, routines, and other ingredients that go to make up the practices of comfort, cleanliness, drying laundry and so on within which the provision of domestic heat and hot water are located are critical in shaping the process of domestication and the extent to which new technologies can play the role envisaged by their designers.

In working towards broadening the uptake of ASWHPs, these findings point to the importance of attending to how new domestic technologies can be more productively introduced and interwoven into household practices. A better system of provision is required if ASWHPs are to be welcomed as an advancement in the provision of heating and hot water for social housing and their reputation is to be enhanced.

\section{Acknowledgements}

The research project through which this work was conducted has been funded under the Low Carbon Network Fund (LCNF). The authors thank the Editor and three anonymous reviewers who provided constructive suggestions during the revision process. Dr Cecily Maller provided feedback on an earlier draft of this paper. 


\section{Notes}

1 The Coefficient of Performance (COP) is the ratio of heat output to electrical input for the technology, a measure of energy efficiency. A higher COP denotes higher efficiency. An alternative standard of performance, the Seasonal Performance Factor (SPF) is a measure of seasonal efficiency, which is defined as the useful thermal energy delivered over the year divided by the electricity input over a year, and may be a more realistic measure. This is typically lower than the COP measured at any one point in time.

2 Further details of the technologies trialled is provided on the CLNR website at http://www.networkrevolution.co.uk.

\section{References}

Aune M (2001) Energy technology and everyday life-The domestication of Ebox in Norwegian households, Proceedings of the European Council for an Energy Efficient Economy (ECEEE) Summer Study. Available at: http://www.eceee. org/library/conference_proceedings/ eceee_Summer_Studies/2001/Panel_4/ p4_1 (accessed 24.04.2014).

Bauman Z (2013) Consuming Life. Wiley.

Bergman N (2013) Why is renewable heat in the UK underperforming? A sociotechnical perspective. Proceedings of the Institution of Mechanical Engineers, Part A: Journal of Power and Energy 227(1): 124-131.

BERR (2008) Microgeneration strategy progress report. London: Department of Business and Regulatory Reform (BERR), June 2008. Available at: http:// webarchive.nationalarchives.gov. uk/20081230194806/berr.gov.uk/ whatwedo/energy/sources/sustainable/ microgeneration/strategy/page27594. html (accessed 05.01.2015).
Bessant J \& Rush H (1995) Building bridges for innovation: the role of consultants in technology transfer. Research Policy 24(1): 97-114.

Boait PJ, Fan D \& Stafford A (2011) Performance and control of domestic ground-source heat pumps in retrofit installations, Energy and Buildings 43(8): 1968-1976.

Bradford J \& Byrne T (2013) The UK heat pump field trial: findings from phase 2 . ECEEE 2013 Summer Study 1971-1077. The European Council for an Energy Efficient Economy (ECEEE).

Brinkley A \& Mcllveen R (2010) Running on Empty: Coming to terms with gas dependence. In: Policy Exchange, January 2010. Available at: http:// www.policyexchange.org.uk/images/ publications / running $\% 20$ on $\% 20$ empty\%20-\%20jan\%2010.pdf (accessed 23.07.2013).

Caird S, Roy R \& Potter S (2012) Domestic heat pumps in the UK: user behaviour, satisfaction and performance. Energy Efficiency 5(3): 283-301.

Cantor J (2011) Air source heat pumps -friend or foe? A review of current technology and its viability. In: The Association for Environment Conscious Building (AECB), 27 July. Available at: http://www.aecb.net/publications/ air-source-heat-pumps-friend-or-foe (accessed 15.05.2013).

Chappells H, Klintman M, Lindén A L, Shove E, Spaargaren G \& van Vliet B (2000) Domestic consumption, utility services and the environment. Final Domus report. Wageningen: Wageningen University, February 2000. Available at: http:// www.wageningenur.nl/en/Publicationdetails.htm?publicationId=publicationway-3634313835 (accessed 08.07.2015).

Chappells H \& Shove E (2004) Infrastructure, crises and the orchestration of demand. In: Southerton D Chappells H \& van Vliet 
B (eds) Sustainable consumption: the implications of changing infrastructures of provision. Cheltenham: Edward Elgar, 130-143.

Christensen TH, Gram-Hanssen K, Petersen PE, Larsen TF, Gudbjerg E, Rasmussen LS \& Munter P (2011) Air-to-air heat pumps: A wolf in sheep's clothing? In: Energy efficiency first: The foundation of a lowcarbon society, Proceedings of the ECEEE Summer Study 2011, 1963-1974.

DCLG (2013) English Housing Survey for 2011-2013. In: UK: Department of Communities \& Local Government. Available at: https://www.gov.uk/ government/uploads/system/uploads/ attachment_data/file/88370/EHS_ Headline_Report_2011-2012.pdf (accessed 14.05.2013).

DCLG (2014) Heat pumps. In: UK: Department of Communities \& Local Government. Available at: http:// www.planningportal.gov.uknprojects/ heatpumps/ (accessed 29.04.2014).

DECC (2013) United Kingdom housing energy fact file. In: UK: Department of Energy \& Climate Change. Available at: https://www.gov.uk/government/ uploads/system/uploads/attachment_ data/file/274766/uk_housing_fact_ file_2013.pdf (accessed 29.04.2014).

DECC (2013a) The Future of Heating: Meeting the challenge. In: $U K$ : Department of Energy \& Climate Change. Available at: https://www.gov.uk/ government/publications/the-futureof-heating-meeting-the-challenge (accessed 13.10.2015).

DECC (2013b) Renewable Heat Incentive. In: UK: Department of Energy \& Climate Change. Available at: https://www.gov. uk/government/policies/increasingthe-use-of-low-carbon-technologies/ supporting-pages/renewable-heatincentive-rhi (accessed 15.05.2013).
DECC (2013c) Performance of exhaust air source heat pumps: summary of detailed monitoring results. In: UK: Department of Energy \& Climate Change. Available at: https://www.gov.uk/government/ publications / examination-ofperformance-of-air-source-heat-pumpsin-a-london-social-housing-block (accessed 27.09. 2013).

DECC (2011) UK Renewable Energy Roadmap. In: UK: Department of Energy \& climate Change. Available at: https:// www.gov.uk/government/uploads/ system/uploads/attachment_data/ file/48128/2167-uk-renewable-energyroadmap.pdf (accessed 10.05.2013).

EHPA (European Heat Pump Association) (2010) European Heat Pump News 12(2) August 2010.

Elzen B, Geels FW \& Geels KG (2004) System innovation and the transition to sustainability: theory, evidence and policy. Cheltenham: Edward Elgar.

Element Energy \& NERA (2011) Achieving deployment of renewable heat. Final report to the Committee on Climate Change, April 2011. Available at: http:// www.element-energy.co.uk/wordpress/ wp-content/uploads/2012/05/CCCRenewable-Heat-final-report_06.05.11. pdf (accessed 16.04.2014).

EST (2013) The heat is on: heat pump field trials Phase 2. London: Energy Saving Trust.

EST (2010) Getting warmer: a field trial of heat pumps. London: Energy Saving Trust.

EST \& Scottish Government (2008) The Scottish Renewables Heating Pilot-An Operational Perspective. London: Energy Saving Trust.

EST (2007) Generating the future: An analysis of policy interventions to achieve widespread microgeneration penetration. Report for the Department for Business, Enterprise and Regulatory Reform (BERR). London: Energy Saving Trust. 
EU (2009) Directive 2009/28/EC of the European Parliament and of the Council of 23 April 2009 on the promotion of the use of energy from renewable sources and amending and subsequently repealing Directives 2001/77/EC and 2003/30/EC. In: European Parliament \& Council, Official Journal of the European Union L159/230, 10.10.2013.

Fawcett T (2011) The future role of heat pumps in the domestic sector. In: Proceedings of the ECEEE 2011 Summer Study, Energy Efficiency First: the foundation of a low-carbon society. The European Council for an Energy Efficient Economy (ECEEE).

Geels FW (2004) From sectoral systems of innovation to socio-technical systems: Insights about dynamics and change from sociology and institutional theory. Research Policy 33(6-7): 897-920.

Gleeson C P \& Lowe R (2013) Meta-analysis of European heat pump field trial efficiencies. Energy and Buildings 66: 637-647.

Gram-Hanssen K, Christensen TH \& Petersen PE (2012) Air-to-air heat pumps in real-life use: Are potential savings achieved or are they transformed into increased comfort? Energy and Buildings 53: 64-73.

Haddon L (2006) Empirical studies using the domestication framework. In: Berker T, Hartmann M, Punie Y \& Ward K (eds) Domestication of Media and Technology. New York: McGraw-Hill, 103-122.

Heiskanen E, Hyysalo S, Jalas M, Juntunen JK \& Lovio R (2014) User Involvement and Radical Innovation: The Case of Heat Pumps in Finland. In: Juninger S \& Christensen P (eds) Highways and Byways of Radical Innovation: The Perspective of Design. Kolding Design School: Kolding.
Hoggett R, Ward J \& Mitchell C (2011) Heat in homes: customer choice on fuel and technologies. Study for Scotia Gas Networks, July 2011. Available at: http:// geography.exeter.ac.uk/staff_profile_ images/Hoggett2011_Heat_in_Homes. pdf (accessed 16.04.2014).

HM Government (2009) The UK Low Carbon Transition Plan. National Strategy for Climate and Energy, London: HMSO. Available at: http://www. official-documents.gov.uk/document/ other/9780108508394/9780108508394. asp (accessed 24.07.2014).

Howells J (2006) Intermediation and the Role of Intermediaries in Innovation. Research Policy 35(5): 715-728.

Hyysalo S, Juntunen JK \& Freeman S (2013) Internet forums and the rise of the inventive energy user. Science and Technology Studies 26(1): 25-51.

IEA (2004) Heat Pump Centre Newsletter 22(2).

IEA (2010) Retrofit heat pumps for buildings: final report. Available at: http://www.heatpumpcentre.org/en/ projects/completedprojects/annex30/ publications / Documents / AN30_ finalreport.pdf (accessed 17.04.2014).

Juntunen JK (2014) Domestication pathways of small-scale renewable energy technologies. Sustainability: Science, Practice, \& Policy 10(1). Available at: http://sspp-prod-cdn-523383718.useast-1.elb.amazonaws.com/archives/ vol10iss 2/1206-030.juntunen.html (accessed 10.06.2014).

Juntunen J (2012) Domestication of smallscale renewable energy systems-A case study of air heat pumps, residential micro wind stations and solar thermal collectors in Finland. In: Matsumoto M, Umeda Y, Masui K \& Fukushige S (eds) Design for Innovative Value Towards a Sustainable Society. Netherlands: Springer. 
Miara M, Günther D \& Langner R (2013) Efficiency of heat pump systems under real operating conditions. In: IEA Heat Pump Center Newsletter 31 (2013) No. 2: 22-26. Available at: http://publica. fraunhofer.de/documents/N-256404. html (accessed 30.11.2014).

Motiva (2010) Jälkiasennetun ilmalämpöpumpun vaikutus energiankäyttöön. Available at: http://www.motiva.fi/files/3960/ Jalkiasennetun_ilmalampopumpun vaikutus_energiankayt toon.pdf (accessed: 26.11.2015).

NERA \& AEA (2009) The UK Supply Curve for Renewable Heat. Study for the Department of Energy and Climate Change. Available at: http://webarchive.nationalarchives.gov.uk/20110123082441/ http://decc.gov.uk/assets/decc/ What\%20we\%20do/UK\%20energy\%20 supply/Energy\%20mix/Renewable\%20 energy/Renewable\%20Energy\%20 Strategy/1_20090715120507_e_@@_ NERAAEATheUKSupplyCurveforRenewableHeaturn09689.pdf (accessed 29.04.2014).

Nordman R (2012) SEasonal PErformance factor and MOnitoring for heat pump systems in the building sector SEPEMOBuild. Final report. Available online: http://ec.europa.eu/energy/intelligent/ projects/sites/iee-projects/files/ projects/documents/sepemo-build final_report_sepemo_build_en.pdf (accessed 26.11.2015).

ONS (2014) Trends in the United Kingdom Housing Market, September 2014. In: UK: ONS. Available at: http://www.ons. gov.uk/ons/rel/hpi/house-price-indexguidance/trends-in-the-uk-housingmarket-2014/housing-trends-article. html (accessed 6.07.2015).

Owen A, Mitchell lG \& Unsworth R (2012) Reducing carbon, tackling fuel poverty: adoption and performance of air-source heat pumps in East Yorkshire, UK. Local Environment: The International Journal of Justice and Sustainability 18(7): 1-17.

Pantzar M (1997) Domestication of Everyday Life Technology: Dynamic Views on the Social Histories of Artefacts. Design Issues 13(3): 52-65.

Pither A \& Doyle N (2005) Hard to treat group: UK heat pump study. In: Energy Efficiency Partnership for Homes. Available at: http://www.docstoc.com/ docs/75718256/Heat-Pumps-Study (accessed 4.10.2013).

Reckwitz A (2002) Toward a Theory of Social Practices. European Journal of Social Theory 5(2): 243-263.

Roy R, Caird S \& Abelman J (2008) YIMBY Generation-yes in my back yard! UK householders pioneering microgeneration heat. London: The Energy Saving Trust. Available at: http://oro.open. ac.uk/10828/1/24660_EST.pdf (accessed 29.04.2014.

Russ CM, Miara M, Platt M, Günther D, Kramer T, Dittmer H, Lechner T \& Kurz C (2010) Feldmessung Wärmepumpen im Gebäudebestand (Heat pump field trial in existing buildings). Available at: http://www.wp-im- gebaeudebestand. de/download/WP im Gebaeudebestand Kurzfassung.pdf (accessed 11.06.2014).

Schatzki T (2015) Practices, Governance and Sustainability In: Strengers Y \& Maller C (eds) Social practices, Interventions and Sustainability: Beyond Behaviour Change. Abingdon, UK: RoutledgeEarthscan, 15-30.

Shove E, Pantzar M \& Watson M (2012) The Dynamics of Social Practice: Everyday Life and how it Changes. London: SAGE Publications.

Shove E \& Walker G (2010) Governing transitions in the sustainability of everyday life. Research Policy 39(4): 471476. 
Singh H, Muetze A \& Eames PC (2010) Factors influencing the uptake of heat pump technology by the UK domestic sector. Renewable Energy 35(?): 873-878.

Sofoulis Z \& Williams C (2008) From Pushing Atoms to Growing Networks: Cultural Innovation and Co-Evolution in Urban Water Conservation. Social Alternatives 27(3): 50-57.

South Tyneside Homes (2012) Introducing renewable projects to social housing -from finding finance to educating occupiers. Available at: http://www. therenewablesevent.com/files/reword_ nickhuston.pdf (accessed 29.04.2014).

Southerton D, Chappells H \& van Vliet B (2004) Sustainable Consumption: The Implications of Changing Infrastructures of Provision. Cheltenham: Edward Elgar Publishing.

Spaargaren G (2011) Theories of practices: Agency, technology, and culture: Exploring the relevance of practice theories for the governance of sustainable consumption practices in the new worldorder. Global Environmental Change 21(3): 813-822.

Spiers J, Gross R, Deshmukh S, Heptonstall P, Munuera L, Leach M \& Torriti J (2010) Heat delivery in a low carbon economy. London: Combined Heat and Power Association. Available at: http://www. chpa.co.uk/medialibrary/2011/04/07/ e9a9f61d/Building_a_roadmap_for_ heat_Full.pdf (accessed 29.04.2014).

Staffell I, Brett D, Brandon N \& Hawkes A (2012) A review of domestic heat pumps. Energy \& Environmental Science 5(11): 9291-9306.

Staffell I, Brett DJL, Brandon NP \& Hawkes AD (2015) Domestic Microgeneration: Renewable and Distributed Energy Technologies, Policies and Economics. Abingdon \& New York: Routledge.
Stafford A \& Lilley D (2012) Predicting in situ heat pump performance: An investigation into a single ground-source heat pump system in the context of 10 similar systems. Energy and Buildings 49: 536-541.

Stenlund M \& Axell M (2010) Residential ground source heat pump systems-results from a field study in Sweden. Available at: http://www.annex32.net/pdf/articles/ GSHP\%20article_SP_2010.pdf (accessed 11.06.2014).

Stewart J \& Hyysalo S (2008) Intermediaries, Users and Social Learning in Technological Innovation. International Journal of Innovation Management 12(3): 295-325.

Stewart J (2007) Local experts in the domestication of information and communication technologies. Information, Communication \& Society 10(4): 547-569.

Strathern M (1994) Foreword: The Mirror of Technology. In: Silverstone R \& Hirsch E (eds) Consuming Technologies: Media and Information in Domestic Spaces. Routledge, vi-x.

Strengers Y (2013) Smart Energy Technologies in Everyday Life: Smart Utopia? ?: Palgrave Macmillan.

Strengers Y \& Maller C (2012) Materialising energy and water resources in everyday practices: Insights for securing supply systems. Global Environmental Change 22(?): 754-763.

Stockton H (2011) Delivering socially just low-carbon solutions: The role of airsource heat pumps in reducing domestic energy use and achieving affordable warmth. Report prepared by National Energy Action for the Ebico Trust, June 2011. 
van Vliet BJM (2012) Sustainable Innovation in Network-Bound Systems: Implications for the Consumption of Water, Waste Water and Electricity Services. Journal of Environmental Policy \& Planning 14(3): 263-278.

Van Vliet B, Chappells H \& Shove E (2005) Infrastructures of Consumption: Environmental Innovation in the Utility Industries. London: Earthscan LLC.

Walker G \& Cass N (2007) Carbon reduction, 'the public' and renewable energy: engaging with socio-technical configurations. Area 39(4): 458-469.

Winther $\mathrm{T}$ \& Wilhite $\mathrm{H}$ (2014) The use of heat pumps in Norwegian homes: Accounting for the comfort rebound effect. CREE Working Paper 2/2014. Centre for Development and the Environment (SUM), University of Oslo. Available at: http://www.cree. uio.no/publications/2014_2/Heat_ Pumps_Winther_and_Wilhite_CREE_ WP02_2014.pdf (accessed 24.10.2014).

Wrapson W \& Devine-Wright P (2014) Domesticating' low carbon thermal technologies: Diversity, multiplicity and variability in older person, off grid households. Energy Policy 67: 807-817.
Dr Ellis Judson

(contact details up to 31 December 2015) College of Design and Social Context RMIT University Melbourne, Australia email: ellis.judson@rmit.edu.au (contact details after 1 January 2016) College of Engineering \& Science Victoria University Melbourne, Australia email: ellis.judson@vu.edu.au

Professor Sandra Bell

Department of Anthropology

Durham University

Durham, UK

email: sandra.bell@durham.ac.uk

Professor Harriet Bulkeley

Department of Geography

Durham University

Durham, UK

email: h.a.bulkeley@durham.ac.uk

Dr Gareth Powells

School of Geography, Politics and Sociology Newcastle University

Newcastle upon Tyne, UK

email: gareth.powells@newcastle.ac.uk

Dr Stephen Lyon

Department of Anthropology

Durham University, UK

Durham, UK

email: s.m.lyon@durham.ac.uk 